\title{
Oxidation of surface sediment: effects of disturbance depth and seawater flow speed
}

\author{
Kay Vopel $^{1,2, *}$, Conrad A. Pilditch ${ }^{3}$, Peter Wilson ${ }^{1,2}$, Michael J. Ellwood ${ }^{4}$ \\ ${ }^{1}$ Auckland University of Technology, Earth and Oceanic Sciences Research Institute, Mail No C43, Private Bag 92006, \\ Auckland, New Zealand \\ ${ }^{2}$ National Institute of Water and Atmospheric Research, PO Box 11-115, Hamilton, New Zealand \\ ${ }^{3}$ University of Waikato, Department of Biological Sciences, Private Bag 3105, Hamilton, New Zealand \\ ${ }^{4}$ Department of Earth and Marine Sciences, Research School of Earth Sciences, The Australian National University, \\ Canberra, ACT 0200, Australia
}

\begin{abstract}
Periodic disturbance of surface sediment is a natural feature of marine environments. Following exposure to oxygenated seawater, the disturbed sediment oxidises leading to the recovery of its surface chemistry. Despite its importance for the ecology of the sediment-water interface, the dynamics of this recovery is not well known. We studied the effects of disturbance depth and seawater flow speed on the oxidation of estuarine cohesive sediment in a laboratory flume with microelectrodes. We removed surface sediment to 2 depths (5 and $50 \mathrm{~mm}$ ) and then observed changes in sediment $\mathrm{O}_{2}$ distribution and consumption over $1 \mathrm{~h}$ under conditions of slow and fast flow (3.5 and $7.5 \mathrm{~cm} \mathrm{~s}^{-1}$ ). Measurements were repeated $1 \mathrm{~d}$ later. The consumption of $\mathrm{O}_{2}$ in the treated sediments reached a 'quasi stable state' within $7 \mathrm{~h} \mathrm{(50} \mathrm{mm} \mathrm{depth)} \mathrm{and} 16 \mathrm{~h} \mathrm{(5} \mathrm{mm} \mathrm{depth)} \mathrm{characterised} \mathrm{by} \mathrm{very}$ slow changes due to slow oxidation of reduced solids. Faster flow increased the rate at which sediment from $50 \mathrm{~mm}$ depth oxidised but not that of the sediment from $5 \mathrm{~mm}$ depth. After 20 to $24 \mathrm{~h}$, sediments disturbed to 50 and $5 \mathrm{~mm}$ depths still differed in $\mathrm{O}_{2}$ distribution and consumption, both from each other and from the pre-treatment sediment. Differences in the response of pore water $\mathrm{O}_{2}$ distribution to an abrupt increase in flow speed (3.5 to $7.5 \mathrm{~cm} \mathrm{~s}^{-1}$ ) were also still evident at this time. Our measurements confirmed the results of previous theoretical analyses in that they indicate that the duration of the recovery of the surface sediment chemistry from disturbance and the chemical properties of the recovering sediment are controlled by the kinetics of solute and solid oxidation. Oxidation of reduced solids in disturbed sediment can result in a characteristic chemical signature at the sediment surface that lasts in the order of at least days.
\end{abstract}

KEY WORDS: Cohesive sediment $\cdot$ Oxygen flux $\cdot$ Sediment respiration $\cdot$ Recovery

\section{INTRODUCTION}

The disturbance of the sediment surface by bioturbation is a common feature of coastal marine environments. If frequent and widespread, it can affect important ecosystem functions such as the decomposition of organic matter and associated regeneration of nutrients for algal and plant growth (e.g. Biles et al. 2002, Norling et al. 2007). Bioturbation also influences other processes that couple the functioning of the sediment and the overlying seawater, for example particle resuspension (Widdows et al. 2004), contaminant cycling
(Williamson et al. 1999), benthic primary production (Vopel et al. 2007) and recruitment (Woodin et al. 1998, Marinelli \& Woodin 2002, 2004). One inevitable consequence of sediment surface disturbance is the exposure of suboxic or reduced sediment to oxygenated seawater. Oxidation will eventually lead to the recovery of the surface sediment chemistry, that is, a new steady state in the depth distributions of redox active sediment constituents. Despite its importance to sediment-water solute fluxes and other interface processes, the dynamics of such redox transitions are not well known. The duration of this transition and the 
properties of the transient sediment are of particular interest because they help determine the effects of bioturbators on sediment-water interface processes. For example, if sediment is repeatedly disturbed by a particular species and the subsequent oxidation process is slow, then knowledge of the chemical properties of redox transient surface sediment becomes important. However, if disturbance (by some other species) occurs infrequently and the oxidation process is rapid, then the overall effect of the transient surface sediment chemistry may be less important.

The time required for the oxidation of disturbed sediment and the properties of the redox transient sediment are a function of bulk sediment and overlying seawater properties, mass transport, the kinetics of chemical and microbial reactions, and faunal activities. Coastal sediments usually exhibit steep vertical concentration gradients in the products of anaerobic mineralization, either in the form of reduced solutes (e.g. $\mathrm{Fe}^{2+}$ and $\mathrm{NH}_{4}{ }^{+}$) or solids (e.g. FeS and $\mathrm{FeS}_{2}$ ). Depending on the depth and frequency of disturbance, $\mathrm{O}_{2}$ will be supplied to sediment containing either reduced solutes or solids, or a mixture of both. The oxidation and evolution of the vertical distribution of these reduced constituents proceed at rates that range over many orders of magnitudes (Berg et al. 2003) and are influenced by the reestablishment of microbial activity. For example, using a modeling approach, Glud et al. (2007) estimated that the oxidation rate of the reduced solutes $\mathrm{Fe}^{2+}$ and $\mathrm{Mn}^{2+}$ declined with a half-life value of $4 \mathrm{~h}$, but the corresponding value for the reduced solids $\mathrm{FeS}$ and $\mathrm{FeS}_{2}$ was $\sim 600 \mathrm{~h}$. This suggests that species that excavate sediment from greater depths (high reduced solids content) are likely to generate a persistent chemical signature in the surface sediment. In contrast, species that disturb only the uppermost millimetre of the sediment (which may be free of reduced solids) may only alter the surface sediment chemistry for short time as recovery involves fast oxidation reactions.

The recovery of disturbed sediments (at least initially) will also be influenced by the presence of a diffusive boundary layer (DBL), which exerts a resistance on solute exchanges. This resistance increases with DBL thickness - a function of near-bed flow speed and bottom roughness. Following a disturbance, a steep concentration gradient will drive the diffusion of reduced solutes from the porewater into the free-flowing bottom water. Eventually, this diffusive flux will be balanced by solute oxidation at some depth in the sediment. The subsurface oxidation of reduced solutes makes up a large fraction of the total sediment $\mathrm{O}_{2}$ demand in diagenetically active coastal sediment and is often indicated by a peak in the $\mathrm{O}_{2}$ consumption profile at the oxic-anoxic boundary. The depth of this oxi- dation zone can migrate in response to a change in the thickness of the DBL so that a similar sediment $\mathrm{O}_{2}$ uptake is maintained at different flow speeds (Jørgensen \& Boudreau 2001). That is, the sediment $\mathrm{O}_{2}$ uptake may be independent of DBL thickness. For example, a reduction in the thickness of the DBL under conditions of fast flow may increase both the depth of the solute oxidation zone and the $\mathrm{O}_{2}$ concentration at the sediment surface but not alter the $\mathrm{O}_{2}$ concentration gradient in the DBL - a measure of the diffusive sediment $\mathrm{O}_{2}$ uptake. In other words, the sediment $\mathrm{O}_{2}$ consumption may not increase in response to a decrease in the DBL thickness, but the depth distribution of $\mathrm{O}_{2}$ consuming processes may adjust. Such adjustment may take only minutes but it could take days if slow oxidation of reduced solids is involved.

The aim of our study was to provide insights into the timescale of the recovery of the sediment surface chemistry following disturbance by different macrofaunal species and the roles that geochemical kinetics and water flow speed play. We cross-sectioned cores of cohesive intertidal sediment at 2 depths to mimic disturbance by surface-dwelling and deep-burrowing macrofauna and then exposed the cross section to fully oxygenated seawater at 2 flow speeds. Using $\mathrm{O}_{2}$ microprofiles we then determined the time required for the oxidation of the freshly exposed sediment. We hypothesised that sediment excavated from deeper layers will oxidise more slowly due to a higher content of reduced solids potentially modifying the chemistry of the sediment-water interface for days. In contrast, we anticipated a faster oxidation of shallow subsurface sediment and a recovery period in the order of hours. We also expected that faster flow via a reduction of the DBL thickness will increase the rate at which disturbed sediment oxidises.

\section{MATERIALS AND METHODS}

Sediment collection. Four treatments incorporating flow speed and depth of disturbance (5 and $50 \mathrm{~mm}$ depth, each at 3.5 and $7.5 \mathrm{~cm} \mathrm{~s}^{-1}$ ) were examined in 4 replicate flume runs that lasted $3 \mathrm{~d}$ each. On the first day of each run, we collected sediment at low tide from an unvegetated intertidal bank in the upper Whau estuary, located on the eastern shore of the North Island, New Zealand (36 53.979' S, $174^{\circ} 40.685^{\prime} \mathrm{E}$ ). The sediment was cohesive muddy sand honeycombed with a network of interconnecting passages, occupied by a population of the endemic grapsid crab Helice crassa Dana, 1851. A thin (3 to $10 \mathrm{~mm}$ ) film of seawater remained on the sediment surface during low tide. We used 10 clear acrylic tubes $\left(20 \mathrm{~cm}^{2} \times 30 \mathrm{~cm}\right)$ to collect sediment cores within $20 \mathrm{~m}$ of a site marker, taking 
care to exclude burrows of $H$. crassa. The tubes were transported to the laboratory within $1.5 \mathrm{~h}$ of collection and then immersed in a bucket filled with aerated seawater (practical salinity $=21$ ). Approximately $1 \mathrm{~h}$ later, we selected 4 tubes and inserted them into the flume described below.

Sediment characterisation. On the first day of each run we sectioned the upper $10 \mathrm{~cm}$ of 1 sediment core into slices $5 \mathrm{~mm}$ thick to characterise vertical variations in sediment water (percent of wet weight) and organic matter (percent of dry weight) content. Sediment water content was determined from the change in weight after drying at $105^{\circ} \mathrm{C}$ for $48 \mathrm{~h}$ and the organic content by weight loss following combustion of dried sediment at $400^{\circ} \mathrm{C}$ for $6 \mathrm{~h}$. The grain-size distribution (percent volume) of the 0 to $2 \mathrm{~cm}$ layer was measured using laser-based measurements of 'time of transition' with a particle analyser (Galai Cis - 100, Galai Productions).

To characterise the redox chemistry of sediment, only once and before the first experimental run we measured $\mathrm{pH}$ and redox potential (Eh) profiles in 2 sediment cores with $\mathrm{pH}$ and Eh microelectrodes (Unisense A/S) and a voltmeter (Knick Portamess ${ }^{\circledR}$, Knick). A motorised micromanipulator moved these and all other microelectrodes used in this study at increments into the sediment from a position starting $1 \mathrm{~mm}$ above the sediment surface to a maximum depth of $65 \mathrm{~mm}$. The software PROFIX (Unisense A/S) controlled the stepwise vertical movement of the micromanipulator by means of a motor controller. We calibrated the $\mathrm{pH}$ microelectrode with $\mathrm{pH}$ buffers (Radiometer Analytical) and tested the function of the Eh electrode with quinhydrone buffer.

A third sediment core was used to measure profiles of $\left[\mathrm{O}_{2}\right],\left[\mathrm{Fe}^{2+}\right],\left[\mathrm{Mn}^{2+}\right],\left[\mathrm{H}_{2} \mathrm{~S}\right]$ and $[\mathrm{FeS}]$ with a solid state 3-electrode voltammetric system consisting of a goldamalgam (Au/Hg) working electrode, a $0.5 \mathrm{~mm}$ diameter platinum wire counter electrode, an $\mathrm{Ag} / \mathrm{AgCl}$ reference electrode and a DLK-100 electrochemical analyser (Analytical Instrument Systems) (Brendel \& Luther 1995). We used linear sweep voltammetry (LSV) to measure $\left[\mathrm{O}_{2}\right]$ and square wave voltammetry (SWV) to measure $\left[\mathrm{Mn}^{2+}\right],\left[\mathrm{Fe}^{2+}\right],\left[\mathrm{H}_{2} \mathrm{~S}\right]$ and $[\mathrm{FeS}]$. The following voltammetric conditions were applied during LSV scans: scan rate $=$ $200 \mathrm{mV} \mathrm{s}^{-1}$, scan range $=-0.10$ to $-1.75 \mathrm{~V}$, step increment $=1 \mathrm{mV}$, equilibrium time $=5 \mathrm{~s}$. SWV was conducted under the same conditions with a pulse height of $24 \mathrm{mV}, 1 \mathrm{mV}$ scan increment and $200 \mathrm{mV} \mathrm{s}^{-1}$ scan rate, and conditioning at $-0.8 \mathrm{~V}$ for $30 \mathrm{~s}$. We extracted voltammetric peaks, wave heights and potentials from scans at each depth increment using a linear background subtraction procedure. Where necessary, we deconvoluted overlapping peaks into 2 Gaussian curves using the software PeakFit ${ }^{\circledR}$ v. 4.1.2 (SeaSolve Software). The voltammetric system was calibrated against $\mathrm{Mn}^{2+}$ standards and the pilot ion method was used to estimate $\left[\mathrm{Fe}^{2+}\right]$ (Brendel \& Luther 1995). Because the electrode sensitivity for FeS was not available, we report FeS as peak current rather than concentration.

Flume and measurement setup. All treatments were examined at ambient temperatures in a recirculating flume (7.23 m long, $50 \mathrm{~cm}$ wide and $50 \mathrm{~cm}$ deep) filled to $15 \mathrm{~cm}$ with $1550 \mathrm{l}$ artificial seawater. Seawater temperature, $\mathrm{pH}$ and salinity (conductivity) were recorded 3 times a day. Seawater temperature varied by $<0.8^{\circ} \mathrm{C}$ on any given day and by $<1.6^{\circ} \mathrm{C}$ among experimental runs (Table 1). Overall, salinity was $20.9 \pm 0.1$ (mean \pm $\mathrm{SD})$ and the $\mathrm{pH}$ was $8.2 \pm 0.1(\mathrm{n}=24)$. Fluorescent lights fitted above the working section of the flume supplied a downwelling irradiance of photosynthetically active radiation of $\sim 70 \mu \mathrm{mol}$ quanta $\mathrm{m}^{-2} \mathrm{~s}^{-1}$ to the sediment surface between 08:30 and 20:00 h (as measured with a plane underwater quantum sensor, LI192SA, LI-COR Environmental). We conducted all electrode measurements within this time.

The sediment cores were placed in 4 holes distributed along a line across the working section of the flume (541 cm downstream from the entrance), perpendicular to the raceway and confined to the central $33 \mathrm{~cm}$ in the cross-stream direction. We measured $\left[\mathrm{O}_{2}\right]$ microprofiles in these cores with a OX50 microelectrode (Unisense A/S) (Revsbech 1989) calibrated in $100 \%$ air-saturated seawater and in seawater that had been deoxygenated with sodium sulfite. Microprofiles of the apparent sediment diffusivity, the product of the sediment porosity $(\phi)$ and the effective diffusion coefficient, $\left(D_{\mathrm{S}}\right)$ were measured with a flow-through hydrogen gas microelectrode (Unisense A/S) calibrated as described by Revsbech et al. (1998). A picoammeter (PA2000, Unisense A/S) polarised the above microelectrodes, amplified their currents and output their signals as a voltage to an analog-digital converter (ADC 216-USB, Unisense A/S). The software PROFIX (Unisense A/S) recorded all electrode signals.
Table 1. Date of sediment collection, flume seawater temperature (mean $\pm \mathrm{SD}$; $\mathrm{n}=6$ ) during the measurements and allocation of combined flow-speed (slow $[\mathrm{S}]=3.5 \mathrm{~cm} \mathrm{~s}^{-1}$; fast $\left.[\mathrm{F}]=7.5 \mathrm{~cm} \mathrm{~s}^{-1}\right)$ and depth-of-disturbance $(5 \mathrm{~mm} ; 50 \mathrm{~mm})$ treatments to each of 4 cores (alpha to delta) for each of 4 runs

\begin{tabular}{|ccccccc|}
\hline \multirow{2}{*}{ Run } & \multirow{2}{*}{$\begin{array}{c}\text { Sampling } \\
\text { date }\end{array}$} & \multirow{2}{*}{$\begin{array}{c}\text { Temperature } \\
\left({ }^{\circ} \mathrm{C}\right)\end{array}$} & Alpha & Beta & Gamma & Delta \\
\hline 1 & 8 Dec 2005 & $18.2 \pm 0.8$ & S 5 & S 50 & F 5 & F 50 \\
2 & 12 Dec 2005 & $19.0 \pm 0.7$ & F 50 & S 5 & S 50 & F 5 \\
3 & 15 Dec 2005 & $18.6 \pm 0.5$ & F 5 & F 50 & S 5 & S 50 \\
4 & 20 Dec 2005 & $17.4 \pm 0.4$ & S 50 & F 5 & F 50 & S 5 \\
\hline
\end{tabular}


Preliminary measurements. To characterise smallscale variation in the flume flow above the 4 sediment cores, we recorded vertical profiles of flow velocity above the centre of each core at heights ranging from 0.8 to $5.8 \mathrm{~cm}(\mathrm{n}=12)$ for a range of free stream flow settings $\left(U=2.4,3.5,5.0,7.5\right.$ and $\left.10.1 \mathrm{~cm} \mathrm{~s}^{-1}\right)$ with a $10 \mathrm{MHz}$ acoustic doppler velocimeter (ADV) (Sontek). The minimum height above the flume floor was chosen so that the bottom boundary was not included in the ADV sample volume (Finelli et al. 1999). $U$ varied by $<10 \%$ with core position, with slightly higher speeds recorded for inner cores compared with the outer cores. Given this low level of variation, and that our experimental design accounted for such variation, we report only mean flow.

In a second series of preliminary measurements, we investigated the thickness of the effective diffusive boundary layer derived from $\mathrm{O}_{2}$-microelectrode measurements $\left(\delta_{\mathrm{O} 2}\right.$, see Glud et al. 2007 for more detail) above cross-sectioned sediment cores as a function of free stream velocity. To do so, we cut sediment to $5 \mathrm{~mm}$ depth, exposed the cut surface to seawater flowing at speeds of 2.4, 5.1, 7.8 and $10.5 \mathrm{~cm} \mathrm{~s}^{-1}$ and measured vertical $\left[\mathrm{O}_{2}\right]$ microprofiles from above the DBL to the start of the anoxic layer (hereafter referred to as complete $\left[\mathrm{O}_{2}\right]$ microprofiles). To produce a smooth cut surface flush with the flume bottom we extruded the sediment out of the tube then cut it with a fine wire, discarding the surface sediment into a sediment trap located $30 \mathrm{~cm}$ downstream from the cores.

Flume measurement sequence. Each of our 4 replicate flume runs lasted 3 d. On Day 1, we inserted 4 sediment cores in the flume and filled the flume. While filling we covered the top of the core barrels, which were flush with the flume floor, with a Petri dish to prevent disturbances to the sediment. After filling, we carefully raised the sediment so that the surface was level with the flume floor. Cores were left for $24 \mathrm{~h}$ at $U=3.5 \mathrm{~cm} \mathrm{~s}^{-1}$ to reestablish porewater solute gradients potentially disturbed during collection and transport of the sediment.

On Day 2 we paused the flume flow to measure the apparent diffusivity of surface sediment (to $5 \mathrm{~mm}$ ) in 2 randomly selected cores $(\mathrm{n}=2$ vertical microprofiles per core). For these and all other microelectrode measurements, we avoided the opening and the area immediately around small amphipod burrows. We then set the flume flow velocity to the flow speed treatment of the core in flume position alpha (e.g. $3.5 \mathrm{~cm} \mathrm{~s}^{-1}$ for Run 1, Table 1) and conducted a sequence of measurements in this core. This sequence was then repeated in the cores in positions beta, gamma and delta with adjustment of the flow speed where necessary. To account for the possible effects of the small cross-stream variations in flow speed we changed the positions of the cores for each run so that each of 4 treatments involving flow speed and depth of disturbance was examined at each position in the flume (Table 1).

The sequence of core measurements commenced with one complete $\left[\mathrm{O}_{2}\right]$ microprofile to derive the $\left[\mathrm{O}_{2}\right]$ at the sediment surface, i.e. $\left[\mathrm{O}_{2}\right]_{\mathrm{z} 0}$, the $\mathrm{O}_{2}$ penetration depth (OPD), the rate of the diffusive $\mathrm{O}_{2}$ uptake (DOU) of the sediment and the total depth-integrated sediment $\mathrm{O}_{2}$ consumption rate $(R)$ for the untreated sediment. We then moved the electrode horizontally and normal to the flow by $\sim 5 \mathrm{~mm}$ and measured $\left[\mathrm{O}_{2}\right]$ microprofiles in the DBL over 30 min at 1-2-min intervals to determine temporal variations in DOU and $\left[\mathrm{O}_{2}\right]_{\mathrm{z} 0}$. One complete $\left[\mathrm{O}_{2}\right]$ microprofile extending from the final DBL microprofile in the time series was obtained just before slicing the core at a depth of either 5 or $50 \mathrm{~mm}$ as previously described. Within $<1$ min after removing the sediment surface, we measured a complete $\left[\mathrm{O}_{2}\right]$ microprofile and then a further 60 min time series of $\left[\mathrm{O}_{2}\right]$ microprofiles within the DBL followed by a final complete $\left[\mathrm{O}_{2}\right]$ microprofile as previously described. When measurements on all 4 cores were completed, we set flume flow to $3.5 \mathrm{~cm} \mathrm{~s}^{-1}$ and left the cores overnight.

On Day 3, more than $20 \mathrm{~h}$ after slicing, we measured 2 complete $\left[\mathrm{O}_{2}\right]$ microprofiles in each of the 4 cores. To investigate the response of sediments to changes in near-bed flow speed 20 to $24 \mathrm{~h}$ after treatment, we measured another $2\left[\mathrm{O}_{2}\right]$ microprofiles in the DBL in one $5 \mathrm{~mm}$ and one $50 \mathrm{~mm}$ cut core immediately before and 17 to 54 min after increasing the flow speed from 3.5 to $7.5 \mathrm{~cm} \mathrm{~s}^{-1}$. Finally, we stopped the flow to measure microprofiles of apparent diffusivity in 2 cores, one core cut to $5 \mathrm{~mm}$ the other to $50 \mathrm{~mm}$ ( $\mathrm{n}=2$ vertical microprofiles per core). We conducted these measurements because we expected deeper sediment to be more compacted than surface sediment.

Parameter estimation and data analysis. The position of the sediment surface in an $\left[\mathrm{O}_{2}\right]$ microprofile was identified by a distinct change in the slope of the profile due to a change in molecular diffusivity between free seawater and sediment (Jørgensen \& Revsbech 1985, Rasmussen \& Jørgensen 1992). The upper DBL boundary was determined as the intersection between the extrapolated linear $\left[\mathrm{O}_{2}\right]$ gradient in the DBL and the constant $\left[\mathrm{O}_{2}\right]$ of the overlying mixed seawater (Jørgensen \& Des Marais 1990).

DOU was derived from the $\mathrm{O}_{2}$ gradient in the DBL (Jørgensen \& Revsbech 1985) as follows:

$$
\left.\mathrm{DOU}=D_{0} \times\left(\left[\mathrm{O}_{2}\right]_{\infty}-\left[\mathrm{O}_{2}\right]_{\mathrm{z} 0}\right) / \delta_{\mathrm{O} 2}\right)
$$

where $\left[\mathrm{O}_{2}\right]_{\infty}$ is the $\left[\mathrm{O}_{2}\right]$ in the turbulent region of the flume seawater and $D_{0}$ is the free-solution diffusion coefficient of $\mathrm{O}_{2}$. Values for $D_{0}$ were taken from 
Broecker \& Peng (1974) and were recalculated to the experimental temperature using the Stokes-Einstein relation (Yuan-Hui \& Gregory 1974). $R$ was computed from the measured $\left[\mathrm{O}_{2}\right]$ microprofiles and sediment porosity using the model PROFILE described in Berg et al. (1998), neglecting the sediment biodiffusivity and irrigation.

To assess the depth distribution of the sediment $\mathrm{O}_{2}$ consumption, we computed profiles of the volumespecific $\mathrm{O}_{2}$ consumption rate $\left(R_{\mathrm{V}}\right)$ using averages of $\left[\mathrm{O}_{2}\right]$ profiles with similar curvature for each sediment/ flow treatment and the profiles of sediment porosity $(\phi)$. The latter profiles were estimated from the measured profiles of apparent diffusivity $\left(\phi \times D_{\mathrm{S}}\right)$ using the equations (Archie 1942, Berner 1980, Ullman \& Aller 1982):

$$
\begin{gathered}
F=D_{0} / \phi \times D_{\mathrm{S}} \\
\phi=(1 / F)^{1 / \mathrm{m}}
\end{gathered}
$$

where $F$ is the formation factor of the sediment and $\mathrm{m}=3$. We then used a fit of the exponential porosity depth profile to calculate the porosity at $0.1 \mathrm{~mm}$ depth intervals matching the resolution of the depth profiles of sediment porosity with that of our measured $\left[\mathrm{O}_{2}\right]$ microprofiles as follows:

$$
\phi_{z}=\phi_{55}+\left(\phi_{0.6}-\phi_{55}\right) \times \mathrm{e}^{-\alpha z}
$$

where $z$ is the sediment depth, $\phi_{0.6}$ and $\phi_{55}$ are the porosities at $0.6 \mathrm{~mm}$ and $55 \mathrm{~mm}$ depth, respectively, and $\alpha$ is an attenuation coefficient $\left(\mathrm{cm}^{-1}\right)$. Differences between treatment (depth of disturbance, flow speed) means of $R$, DOU, $\left[\mathrm{O}_{2}\right]_{\mathrm{z} 0}$ and OPD were examined with Student's $t$-test $(\alpha=0.05)$.

\section{RESULTS}

\section{Sediment properties}

The water content of the silty sand (median grain size $=72 \mu \mathrm{m} ; 1 \%$ clay, $42 \%$ silt, $39 \%$ very fine sand, $18 \%$ fine sand) decreased exponentially from $72.5 \%$ wet weight in the surface layer ( 0 to $5 \mathrm{~mm}$ ) to $55.3 \%$ wet weight at a depth of $10 \mathrm{~cm}$ (Fig. 1A). The organic matter content was low in the surface layer (3\% dry weight), increased slightly from 5 to $10 \mathrm{~mm}$ and then remained constant (from 4 to $5 \%$ ) down to $10 \mathrm{~cm}$. Sediment porosity decreased exponentially $\left(\mathrm{r}^{2}=0.92, \mathrm{n}=8\right)$ from $0.82 \pm 0.12$ at $0.6 \mathrm{~mm}$ depth to $0.76 \pm 0.11$ at $55 \mathrm{~mm}$ depth (Fig. 1B).

Eh remained constant within the upper $3 \mathrm{~mm}$ of the undisturbed sediment, but over the same depth range there was a steep decrease in $\mathrm{pH}$ from 7.7 to 7.1 (Fig. 1C). Between 3 and $10 \mathrm{~mm}$ Eh decreased sharply, and then below $12 \mathrm{~mm}$ the decline in Eh became more gradual. In contrast, after the initial decline $\mathrm{pH}$ remained relatively constant until $\sim 12 \mathrm{~mm}$, after which it began to increase. The corresponding voltammetric profiles confirmed the common diagenetic pattern of $\mathrm{O}_{2}$ disappearance followed by the appearance of $\mathrm{Mn}^{2+}$ and then $\mathrm{Fe}^{2+}$ with depth (Fig. 1D). $\left[\mathrm{Mn}^{2+}\right]$ peaked at a depth between 30 and $40 \mathrm{~mm}$. No free sulphide was detected to $65 \mathrm{~mm}$, which was the maximum depth measured.

The original sediment surface was brownish yellow; cores cut to $5 \mathrm{~mm}$ were light gray with patches of brownish yellow and those cut to $50 \mathrm{~mm}$ were dark gray with patches of light gray (Fig. 2). Inspection of the $5 \mathrm{~mm}$ cut core surfaces revealed small openings of amphipod and polychaete burrows (diameter: $0.37 \pm$ $0.08 \mathrm{~mm}$, mean $\pm \mathrm{SD} ; \mathrm{n}=27$ ) surrounded by darker sediment in some of the cores. No such burrow openings were observed at the surface of the $50 \mathrm{~mm}$ cut cores. Patchy coloration of the new sediment surfaces resulted from spatial heterogeneity in the distribution of $\mathrm{FeS}$ and $\mathrm{FeS}_{2}$ (Fig. 2), which reflects the disturbance history of the sediment. It also explains the high standard deviations of average values for DOU, OPD and $\left[\mathrm{O}_{2}\right]_{\mathrm{z} 0}$, derived from point measurements in the cores.

\section{DBL thickness}

The effective thickness of the DBL $\left(\delta_{\mathrm{O} 2}\right)$ above sediment cut to $5 \mathrm{~mm}$ decreased linearly $\left(\mathrm{r}^{2}=0.98\right)$ from $0.418 \mathrm{~mm}$ at $U=2.4 \mathrm{~cm} \mathrm{~s}^{-1}$ to $0.193 \mathrm{~mm}$ at $U=10.5 \mathrm{~cm} \mathrm{~s}^{-1}$. At our 2 experimental flow speeds of $U=3.5$ and $7.5 \mathrm{~cm} \mathrm{~s}^{-1}$ (hereafter referred to as slow and fast flow), $\delta_{\mathrm{O} 2}$ was 0.37 and $0.22 \mathrm{~mm}$, respectively. Because cut sediment surfaces were similar (flat and flush with the flume floor), we assumed that these $2 \delta_{\mathrm{O} 2}$ values applied to all treated sediment cores.

Untreated sediment had millimetre scale surface topography that varied between cores, which may have influenced $\delta_{\mathrm{O} 2}$. Inspection of the 8 predisturbance time-series $\left[\mathrm{O}_{2}\right]$ profiles, however, revealed that for both the slow and fast flows, mean $\delta_{\mathrm{O} 2}$ was similar to the cut sediment $(0.36 \pm 0.07 \mathrm{~mm}$ [mean $\pm \mathrm{SD}$ ] and $0.23 \pm 0.04 \mathrm{~mm}$, respectively).

\section{Sediment $\mathrm{O}_{2}$ consumption and distribution}

\section{Before treatment}

We excluded 2 sediment cores (Run 2, flume position gamma; Run 3, flume position beta) from the analyses of the pretreatment results because small amphipods populated these cores at exceptionally high densities 
$\square$ Water content (\% wet weight)
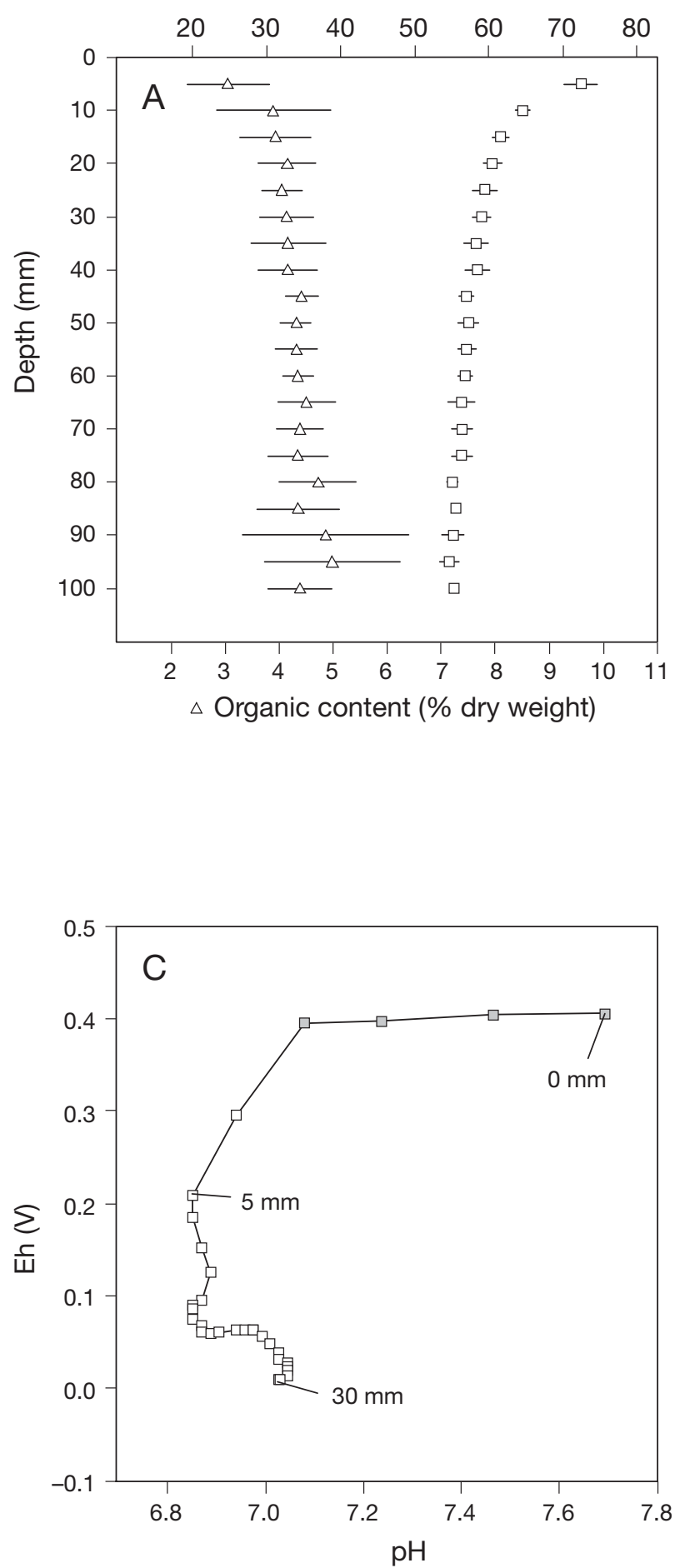

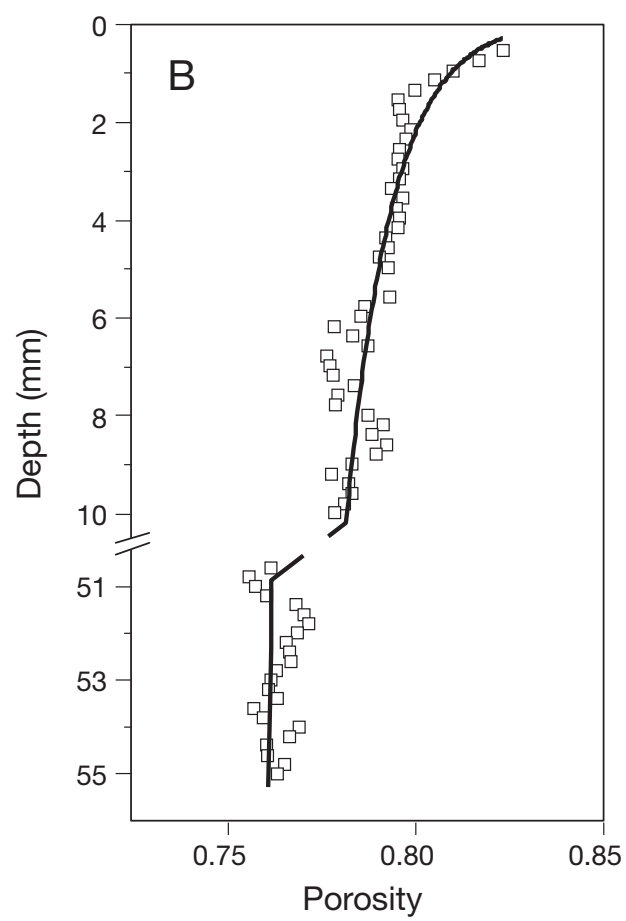

$\left[\mathrm{O}_{2}\right]$ (\% saturation)

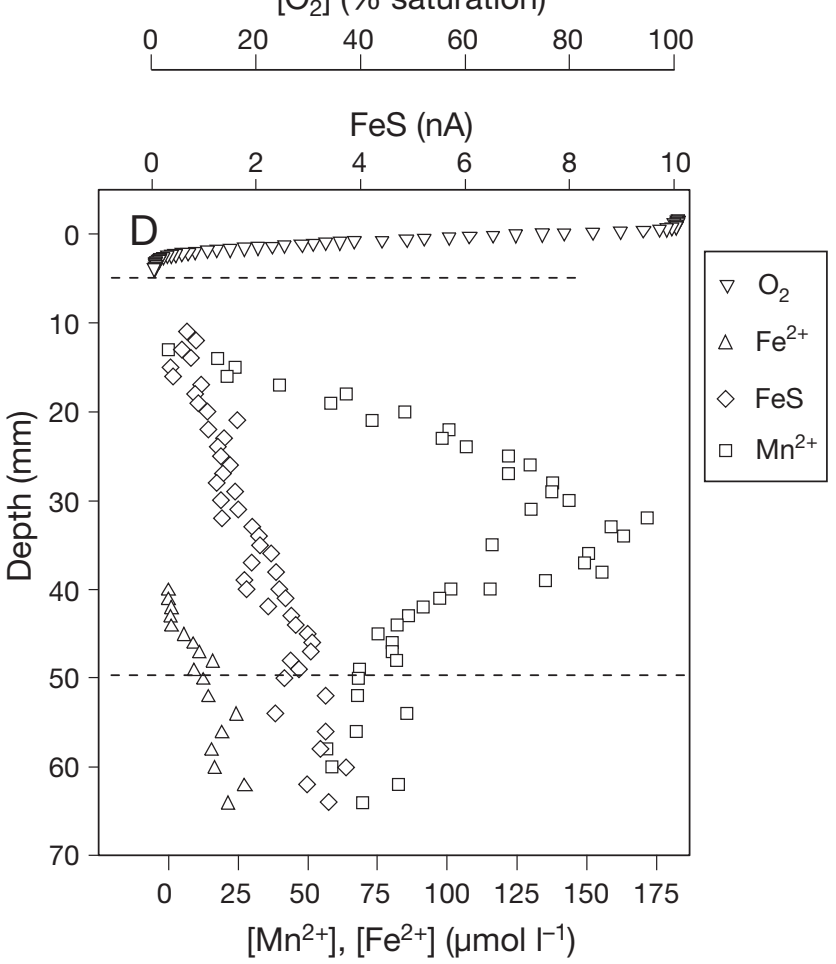

Fig. 1. Depth distribution of (A) sediment water content and organic matter content, (B) porosity, (C) pH-Eh and (D) dissolved $\mathrm{O}_{2}$, $\mathrm{Mn}^{2+}, \mathrm{Fe}^{2+}$ and FeS of undisturbed sediment. (A) Values are mean $\pm \mathrm{SD}$ (water and organic matter content, $\mathrm{n}=4 ;$ porosity, $\mathrm{n}=8$ ). (B) Exponential fit through porosity profile is given by $\phi=0.76+(0.82 \times 0.76) \mathrm{e}^{-0.18 z}\left(\mathrm{r}^{2}=0.92\right)$. Note break in the depth scale (C) $\mathrm{pH}$-Eh diagramshows changes in pore water $\mathrm{pH}$ and $\mathrm{Eh}$ in $1 \mathrm{~mm}$ increments from the sediment-seawater interface (0 mm) to $30 \mathrm{~mm}$ depth. ( $\square$ ) in (C) indicates the presence of $\mathrm{O}_{2}$. (D) Dashed lines indicate the depths to which the sediment was removed during flume experiments 

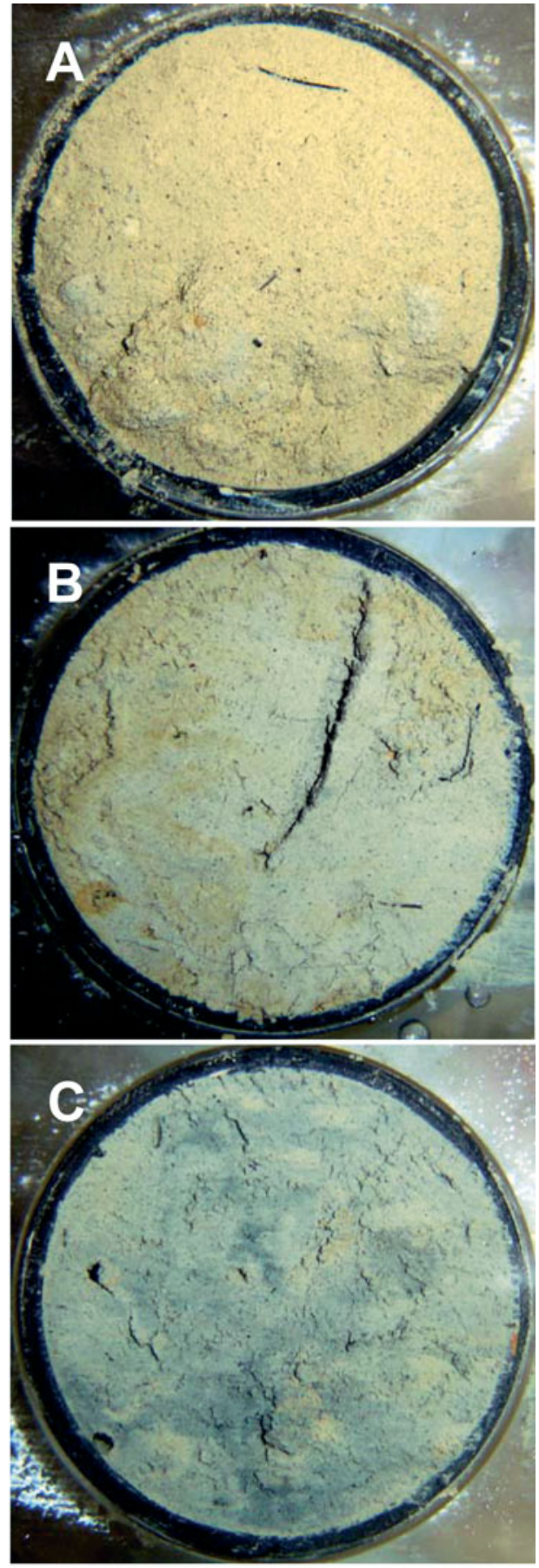

Fig. 2. Photographs of the sediment surface of (A) untreated, (B) $5 \mathrm{~mm}$ and (C) $50 \mathrm{~mm}$ cut cores. The upper rim of the tubes and the surface of the sediment core were flush with the flume bottom. Image contrast was increased by $10 \%$. Tube diameter $=5 \mathrm{~cm}$

leading to OPDs in excess of $6 \mathrm{~mm}$ (data not shown). Under slow-flow conditions, the DOU of untreated sediment ranged from 719 to $1226 \mu \mathrm{mol} \mathrm{m} \mathrm{m}^{-2} \mathrm{~h}^{-1}$ and $\left[\mathrm{O}_{2}\right]_{\mathrm{z} 0}$ from between 73 and $94 \%$ saturation (Fig. 3). Under

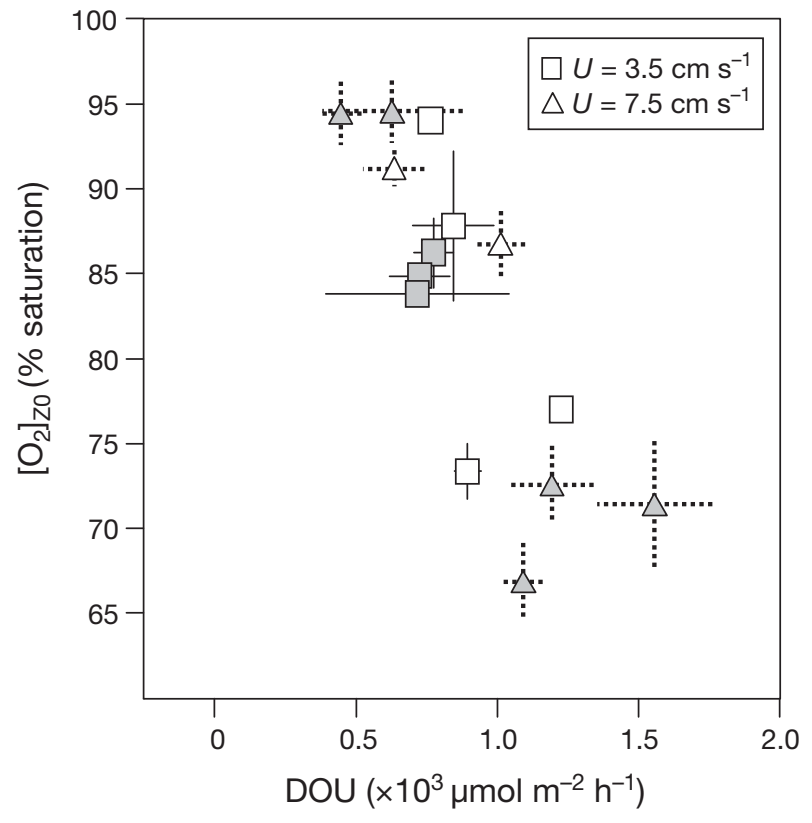

Fig. 3. Variation in diffusive $\mathrm{O}_{2}$ uptake (DOU) and surface $\left[\mathrm{O}_{2}\right]$, i.e. $\left[\mathrm{O}_{2}\right]_{\mathrm{z} 0}$, of undisturbed sediment under conditions of slow $\left(U=3.5 \mathrm{~cm} \mathrm{~s}^{-1}\right)$ and fast $\left(U=7.5 \mathrm{~cm} \mathrm{~s}^{-1}\right)$ flows. The 4 cores in each run (see Table 1) were studied consecutively; thus, periods of either higher or lower flow preceded measurements in some cores. The results from such cores are indicated by filled symbols. Error bars: \pm SD $(n=10)$

fast-flow conditions, the DOU had a greater range, from 447 to $1555 \mu \mathrm{mol} \mathrm{m} \mathrm{m}^{-2} \mathrm{~h}^{-1}$, and $\left[\mathrm{O}_{2}\right]_{\mathrm{z} 0}$ varied between 67 and $95 \%$ saturation. The estimates of $R$ under conditions of slow and fast flow, respectively, were 56 and $66 \%$ lower than those of DOU. Flow speed had no significant effect on DOU, $\left[\mathrm{O}_{2}\right]_{\mathrm{z} 0}$ and OPD; however, fast flow did increase $R$ significantly by $31 \%(\mathrm{p}<0.001)$ compared with slow flow (Table 2$)$. Inspection of the computed profiles of the volume-specific $\mathrm{O}_{2}$ consumption rate, $R_{\mathrm{V}}$, revealed that under both flow conditions $R_{\mathrm{V}}$ was highest in the uppermost layer and lowest at the oxic/anoxic boundary (Fig. 4).

0 to $1 \mathrm{~h}$ after treatment

Immediately (<1 $\mathrm{min}$ ) after removal of the top $5 \mathrm{~mm}$ sediment mean DOU had increased by factors of 5.9 and 5.3 under conditions of slow and fast flow, respectively (Fig. 5, Table 2). The DOU measured under conditions of slow flow did not differ significantly from that measured under conditions of fast flow. In contrast, cores from which surface sediment was removed to a depth of $50 \mathrm{~mm}$ consumed significantly less $\mathrm{O}_{2}$ under conditions of slow flow than under fast flow ( $p=0.044)$; their average DOU were 7.1 and 8.7 times higher than undisturbed sediment at slow and fast flow, respectively. The difference between DOU of cores cut to 5 
Table 2. Mean \pm SD diffusive $\mathrm{O}_{2}$ uptake of the sediment (DOU, $\mu \mathrm{mol} \mathrm{m} \mathrm{m}^{-2} \mathrm{~h}^{-1}$ ), depth integrated rate of sediment $\mathrm{O}_{2}$ consumption $\left(\mathrm{R}, \mu \mathrm{mol} \mathrm{m}{ }^{-2} \mathrm{~h}^{-1}\right), \mathrm{O}_{2}$ penetration depth $(\mathrm{OPD}, \mathrm{mm})$ and $\mathrm{O}_{2}$ concentration at the surface $\left(\left[\mathrm{O}_{2}\right]_{\mathrm{z} 0}\right.$, as \% saturation) of undisturbed and disturbed sediment under conditions of slow $\left(3.5 \mathrm{~cm} \mathrm{~s}^{-1}\right)$ and fast $\left(7.5 \mathrm{~cm} \mathrm{~s}^{-1}\right)$ flows. Parameters were measured before (undisturbed sediment) and $<1 \mathrm{~min}, 1 \mathrm{~h}$ and 20 to $24 \mathrm{~h}$ after removal of surface sediment to depths of 5 or $50 \mathrm{~mm}$. All cores were exposed to slow flow in the time period between the measurements after $1 \mathrm{~h}$ and those after 20 to $24 \mathrm{~h}$. $\mathrm{n}=$ number of replicate measurements. Significant differences between treatment means $(t$-test, $p<0.05)$ are indicated by superscript capital letters, where the 2 values that are significantly different are marked with the same letter

\begin{tabular}{|c|c|c|c|c|c|c|c|}
\hline & $\mathrm{n}$ & $\begin{array}{l}\text { Current speed } \\
\quad\left(\mathrm{cm} \mathrm{s}^{-1}\right)\end{array}$ & $\begin{array}{c}\text { Sediment } \\
\text { depth (mm) }\end{array}$ & $\begin{array}{c}\text { DOU } \\
\left(\mu \mathrm{mol} \mathrm{m}^{-2} \mathrm{~h}^{-1}\right)\end{array}$ & $\underset{\left(\mu \mathrm{mol} \mathrm{m} \mathrm{m}^{-2} \mathrm{~h}^{-1}\right)}{\mathrm{R}}$ & $\begin{array}{l}\mathrm{OPD} \\
(\mathrm{mm})\end{array}$ & $\begin{array}{c}{\left[\mathrm{O}_{2}\right]_{\mathrm{Z} 0}} \\
\text { (\% saturation) }\end{array}$ \\
\hline Undisturbed & 7 & $\begin{array}{l}3.5 \\
7.5\end{array}$ & & $\begin{array}{l}850 \pm 178 \\
938 \pm 388\end{array}$ & $\begin{array}{l}474 \pm 86^{\mathrm{C}} \\
621 \pm 35^{\mathrm{C}}\end{array}$ & $\begin{array}{l}3.20 \pm 1.11 \\
3.19 \pm 1.05\end{array}$ & $\begin{array}{l}84 \pm 7 \\
83 \pm 12\end{array}$ \\
\hline $\begin{array}{l}\text { Disturbed } \\
\text { After }<1 \text { min }\end{array}$ & 4 & $\begin{array}{l}3.5 \\
3.5 \\
7.5 \\
7.5\end{array}$ & $\begin{array}{c}5 \\
50 \\
5 \\
50\end{array}$ & $\begin{array}{l}5015 \pm 2970 \\
6021 \pm 900^{\mathrm{B}} \\
4952 \pm 1865^{\mathrm{A}} \\
8166 \pm 1751^{\mathrm{AB}}\end{array}$ & $\begin{array}{l}- \\
- \\
- \\
-\end{array}$ & $\begin{array}{l}- \\
- \\
- \\
-\end{array}$ & $\begin{array}{l}- \\
- \\
- \\
-\end{array}$ \\
\hline After $1 \mathrm{~h}$ & 4 & $\begin{array}{l}3.5 \\
3.5 \\
7.5 \\
7.5\end{array}$ & $\begin{array}{c}5 \\
50 \\
5 \\
50\end{array}$ & $\begin{array}{l}2407 \pm 665 \\
3252 \pm 783 \\
2521 \pm 1018 \\
3561 \pm 1283\end{array}$ & $\begin{array}{l}- \\
- \\
- \\
-\end{array}$ & $\begin{array}{l}1.3 \pm 0.9 \\
1.5 \pm 1.0 \\
1.5 \pm 0.2 \\
1.5 \pm 0.6\end{array}$ & $\begin{array}{l}66 \pm 19 \\
39 \pm 8 \\
63 \pm 7 \\
46 \pm 26\end{array}$ \\
\hline After 20 to $24 \mathrm{~h}$ & $8^{\mathrm{a}}$ & $\begin{array}{l}3.5 \\
3.5\end{array}$ & $\begin{array}{c}5 \\
50\end{array}$ & $\begin{array}{l}1201 \pm 130^{\mathrm{D}} \\
2060 \pm 560^{\mathrm{D}}\end{array}$ & $\begin{array}{r}547 \pm 105^{\mathrm{E}} \\
1005 \pm 236^{\mathrm{E}}\end{array}$ & $\begin{array}{l}2.4 \pm 0.9^{\mathrm{F}} \\
1.4 \pm 0.7^{\mathrm{F}}\end{array}$ & $\begin{array}{l}85 \pm 3^{\mathrm{G}} \\
71 \pm 7^{\mathrm{G}}\end{array}$ \\
\hline
\end{tabular}



Fig. 4. Average depth distributions of $\left[\mathrm{O}_{2}\right](\square$, lower scale) and volume-specific rates of $\mathrm{O}_{2}$ consumption $\left(R_{\mathrm{V}}\right.$; grey bars, upper scale) in undisturbed sediment under conditions of (A) slow flow $\left(3.5 \mathrm{~cm} \mathrm{~s}^{-1}\right)$ and (B) fast flow $\left(7.5 \mathrm{~cm} \mathrm{~s}^{-1}\right)$. Fit indicates the calculated best-fitting concentration profile (lower scale, $\mathrm{r}^{2}=0.9999$ to 1.0000$)$. Error bars: $\pm \mathrm{SD}(\mathrm{n}=7)$ and $50 \mathrm{~mm}$ was significant only under conditions of fast flow ( $p=0.023)$.

After $1 \mathrm{~h}$ exposure to flume flow, OPD in $5 \mathrm{~mm}$ cut cores were 1.3 and $1.5 \mathrm{~mm}$ under conditions of slow and fast flow, respectively; the average $\left[\mathrm{O}_{2}\right]_{\mathrm{z} 0}$ values were 66 and $63 \%$ saturation. Cores from which the upper $50 \mathrm{~mm}$ was removed had similar OPD $(1.5 \mathrm{~mm}$ for both flow speeds) but the average $\left[\mathrm{O}_{2}\right]_{\mathrm{z} 0}$ was lower for slow flow (39\%) than for fast flow (46\%). The DOU of the cut cores was still 2.7 to 2.8 times (for $5 \mathrm{~mm}$ cores) and 3.8 times (for $50 \mathrm{~mm}$ cores) higher than for the pretreatment DOU, irrespective of flow speed (Fig. 5, Table 2). After $1 \mathrm{~h}$, none of the differences in DOU, OPD and $\left[\mathrm{O}_{2}\right]_{\mathrm{z} 0}$ between any of the combined flow-speed and depth-of-disturbance treatments were statistically significant.

The DOU estimates for one replicate core cut to $50 \mathrm{~mm}$ and tested under conditions of fast flow were exceptionally low (open circles in Fig. 5D). Eliminating these outliers (Dixon test, $\mathrm{p}<0.05$, Verma \& QuirozRuiz 2006) from the analysis revealed differences similar to those observed immediately ( $<1 \mathrm{~min})$ after core treatment: a significant difference between mean DOU for slow $\left(3252 \pm 783 \mu \mathrm{mol} \mathrm{m} \mathrm{m}^{-2} \mathrm{~h}^{-1}\right)$ and fast $(4196 \pm$ $\left.220 \mu \mathrm{mol} \mathrm{m}{ }^{-2} \mathrm{~h}^{-1}\right)$ flow treatments $(\mathrm{p}=0.045)$, and a significant difference $(p=0.021)$ between DOU of cores cut to 5 and $50 \mathrm{~mm}$ depths under conditions of fast flow.

\section{0 to $24 \mathrm{~h}$ after treatment}

In the following, we ignore any effects of early exposure of cores to $1 \mathrm{~h}$ periods of different flow speeds and simply combine all results for cores cut to either 5 or 



Fig. 5. Time series of diffusive $\mathrm{O}_{2}$ uptake (DOU) of 4 sediment cores under conditions of $(\mathrm{A}, \mathrm{B})$ slow flow $\left(3.5 \mathrm{~cm} \mathrm{~s}^{-1}\right)$ and $(\mathrm{C}, \mathrm{D})$ fast flow $\left(7.5 \mathrm{~cm} \mathrm{~s}^{-1}\right)$ before and after their surface layers were removed to 5 and $50 \mathrm{~mm}$ depths. DOU was calculated from the $\left[\mathrm{O}_{2}\right]$ gradient in the diffusive boundary layer above the sediment measured at one location for each time series
$50 \mathrm{~mm}$ depths. After 20 to $24 \mathrm{~h}$ exposure to slow flume flow, cores cut to a depth of $50 \mathrm{~mm}$ consumed significantly more $\mathrm{O}_{2}$ than did those cut to $5 \mathrm{~mm}$ depth (DOU: $\mathrm{p}=0.002, R: \mathrm{p}<0.001$; Table 2). Furthermore, DOU averages for both core treatments were significantly higher $(5 \mathrm{~mm}$ cut: $\mathrm{p}=0.002 ; 50 \mathrm{~mm}$ cut: $\mathrm{p}<0.001$ ) than the average of all pretreatment cores at both flow speeds. Average $R$ was similar to the pretreatment rate for the cores cut to $5 \mathrm{~mm}$ depth but significantly higher ( $p<0.001$ ) for cores cut to $50 \mathrm{~mm}$ depth. Inspection of the $\mathrm{O}_{2}$ consumption profiles revealed that, in contrast to the pre treatment cores, the volume-specific $\mathrm{O}_{2}$ consumption rate, $R_{\mathrm{V}}$, in the 5 and $50 \mathrm{~mm}$ cut cores peaked respectively at depths below 1.0 and $0.5 \mathrm{~mm}$ rather than at the surface (compare Figs. 4 and 6). The average OPD had increased significantly ( $p=$ 0.003 ) from $1.36 \pm 0.63$ (both flow treatments after $1 \mathrm{~h}$ combined) to $2.4 \mathrm{~mm}$ in cores cut to $5 \mathrm{~mm}$ depth, whereas no such increase was observed in cores cut to $50 \mathrm{~mm}$ depth. The average $\left[\mathrm{O}_{2}\right]_{\mathrm{z} 0}$ of the $5 \mathrm{~mm}$ cut sediment cores was similar to that of untreated cores, but $\left[\mathrm{O}_{2}\right]_{\mathrm{zo}}$ of $50 \mathrm{~mm}$ cut cores was still significantly $(p=0.002)$ lower at $71 \%$ saturation (Table 2 ).

\section{Sediment response to increasing flow speed}

After 20 to $24 \mathrm{~h}$ exposure to slow flow, the distribution of $\mathrm{O}_{2}$ in the 2 depth-ofdisturbance treatments responded differently to a sudden increase in flow speed from 3.5 to $7.5 \mathrm{~cm} \mathrm{~s}^{-1}$ (reduction in $\delta_{\mathrm{O} 2}$ from $\sim 0.37$ to $\sim 0.22 \mathrm{~mm})$. An increase in flow speed raised $\left[\mathrm{O}_{2}\right]_{\mathrm{z} 0}$ in both treatments but the magnitude of this increase differed (Fig. 7). The dashed line in Fig. 7 indicates the theoretical relationship between $\left[\mathrm{O}_{2}\right]_{\mathrm{z} 0}$ and $\Delta\left[\mathrm{O}_{2}\right]_{\mathrm{z} 0}$ under the assumption that the sediment maintains a constant DOU following a reduction in $\delta_{\mathrm{O} 2}$ (see Eq. 1 and Jørgensen \& Boudreau 2001). The sediment treatments deviated from this relationship to different extents. $\Delta\left[\mathrm{O}_{2}\right]_{\mathrm{z} 0}$ for the $5 \mathrm{~mm}$ cut cores were close to the calculated values required to maintain DOU, but those for the $50 \mathrm{~mm}$ cut cores were far below calculated values. 


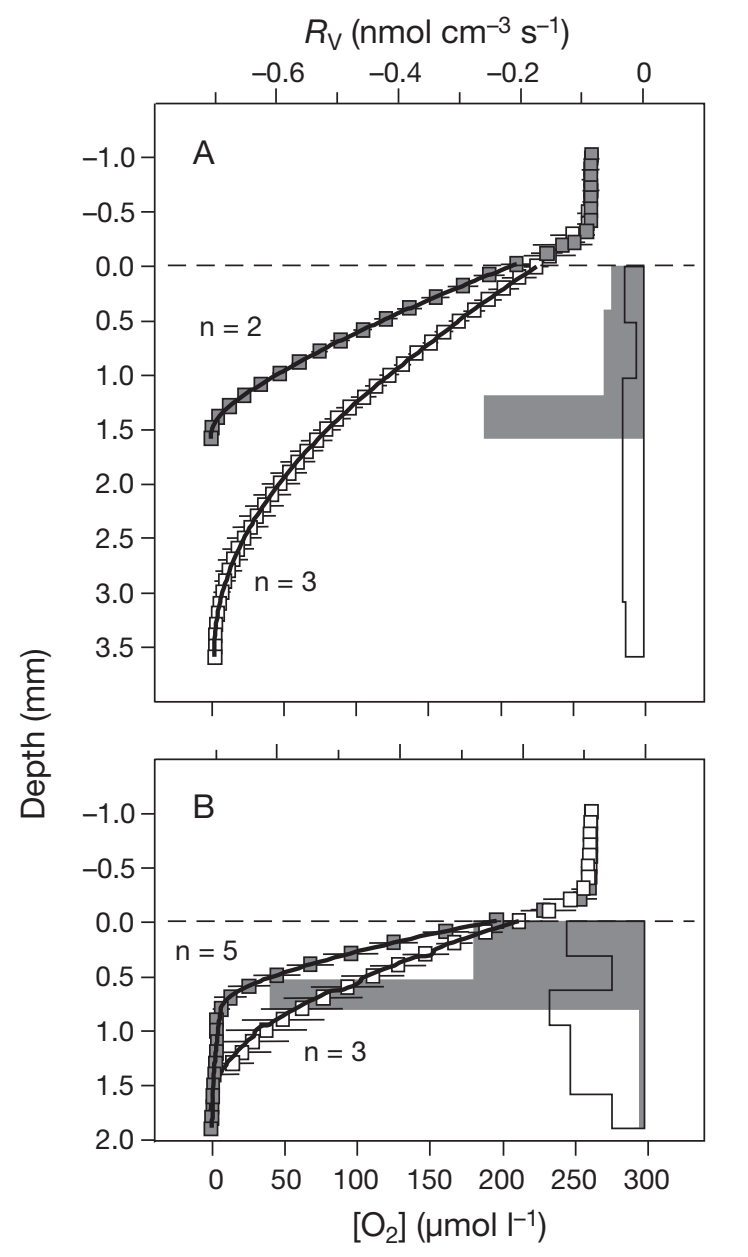

Fig. 6. Average depth distributions of $\left[\mathrm{O}_{2}\right]$ (squares, lower scale) and volume specific rates of $\mathrm{O}_{2}$ consumption $\left(R_{\mathrm{V}}\right.$ grey and open bars, upper scale) in sediment cores under conditions of slow flow $\left(U=3.5 \mathrm{~cm} \mathrm{~s}^{-1}\right) 20$ to $24 \mathrm{~h}$ after surface layers were removed to (A) $5 \mathrm{~mm}$ and (B) $50 \mathrm{~mm}$ depths. $R_{\mathrm{V}}$ profiles were computed using averages of similar shaped $\left[\mathrm{O}_{2}\right]$ profiles and those average profiles that spanned the range of $\mathrm{O}_{2}$ penetration depths are plotted. Fit indicates the calculated best-fitting concentration profile (lower scale, $\mathrm{r}^{2}=0.9999$ to 1.0000). Error bars: $\pm \mathrm{SD}$

The difference between the theoretical and the measured $\Delta\left[\mathrm{O}_{2}\right]_{\mathrm{zo}}$ increased with increasing $\left[\mathrm{O}_{2}\right]_{\mathrm{z} 0}$ of both core treatments, but the difference was more apparent in the $50 \mathrm{~mm}$ cut cores.

\section{DISCUSSION}

Our time series of the DBL $\left[\mathrm{O}_{2}\right]$ gradient indicate that the oxidation of the cut sediment proceeded rapidly during the first minutes after contact with oxygenated seawater, but low OPD and $\left[\mathrm{O}_{2}\right]_{\mathrm{z} 0}$, and high DOU persisted for at least $1 \mathrm{~d}$ for sediment cut to $50 \mathrm{~mm}$. The decrease in the steepness of the DBL $\left[\mathrm{O}_{2}\right]$ gradient

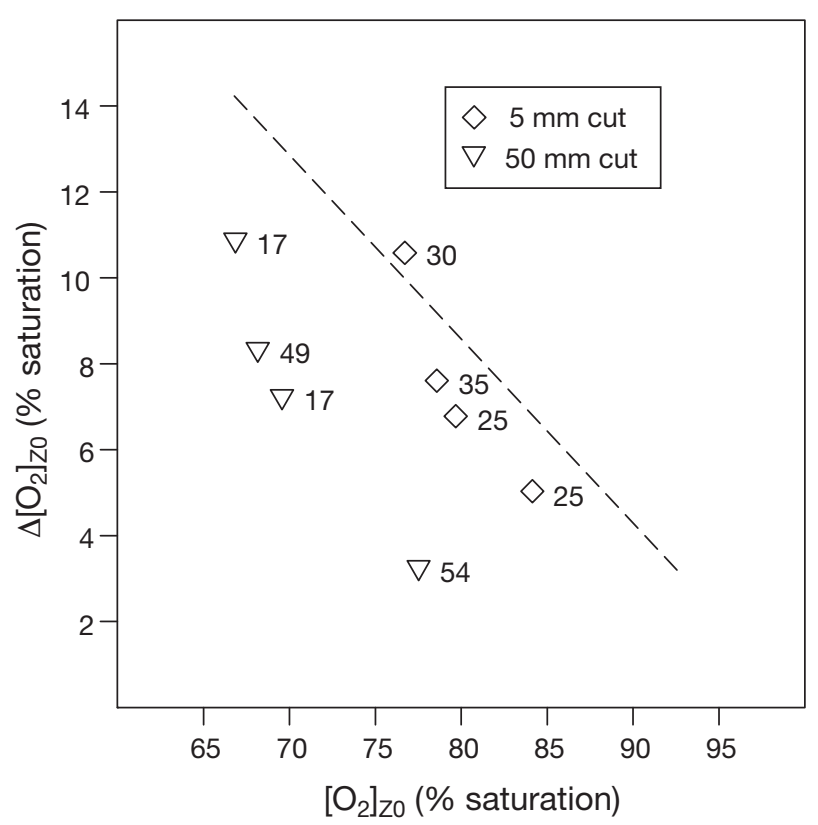

Fig. 7. Increase in the sediment surface $\left[\mathrm{O}_{2}\right]$, i.e. $\Delta\left[\mathrm{O}_{2}\right]_{\mathrm{zo} 0}$, following an increase in flow speed from 3.5 to $7.5 \mathrm{~cm} \mathrm{~s}^{-1}$ more than $20 \mathrm{~h}$ after sediment was cut to the $5(\diamond)$ or $50 \mathrm{~mm}(\nabla)$ depth. $\left[\mathrm{O}_{2}\right]_{z 0}$ (X-axis) was measured immediately before increasing the flow speed and the numbers next to symbols are time in minutes between the increase in flow speed and remeasurement of $\left[\mathrm{O}_{2}\right]_{z_{0}}$. Dashed line indicates the theoretical relationship between $\Delta\left[\mathrm{O}_{2}\right]_{\mathrm{z} 0}$ and $\left[\mathrm{O}_{2}\right]_{\mathrm{zo}}$ under the assumption that a reduction of the diffusive boundary layer (DBL) thickness changes the distribution of $\mathrm{O}_{2}$ in the sediment but not the $\left[\mathrm{O}_{2}\right]$ gradient in the DBL

(used to calculate DOU) during the first few minutes following sediment sectioning of the $5 \mathrm{~mm}$ cut sediment was apparently due to oxidation and diffusive loss of reduced solutes from the sediment porewater. The data shown in Fig. 1D suggest that $\mathrm{Fe}^{2+}$ and $\mathrm{Mn}^{2+}$ may not have been present at $5 \mathrm{~mm}$ depth; therefore, this trend may be driven by a decrease in porewater $\left[\mathrm{NH}_{4}{ }^{+}\right]$. Note, however, that the single-point voltammetric profiles shown in Fig. 1D cannot account for spatially heterogeneous solute distributions.

Extrapolation of the exponential decline in DOU observed for the $5 \mathrm{~mm}$ cut sediment cores (Fig. 5A, $\mathrm{r}^{2}>$ $0.90, \mathrm{n}=2$ ) under the condition of slow flow revealed that this sediment reached the consumption measured after 20 to $24 \mathrm{~h}$ (Table 2) within $16 \mathrm{~h}$. In contrast, the $50 \mathrm{~mm}$ cut sediment (Fig. 5B, $\mathrm{r}^{2}>0.82$ for all replicates) reached this 'final' $\mathrm{O}_{2}$ consumption in only $7 \mathrm{~h}$. We believe that the $5 \mathrm{~mm}$ cut sediment reached its new 'quasi steady state' - characterised by very slow changes in the sediment $\mathrm{O}_{2}$ distribution - later than the $50 \mathrm{~mm}$ cut sediment because this required the oxidation of a larger pool of reduced porewater solutes. Over time, the concentrations of reduced solutes in the 
porewater decreased and the zone of their oxidation moved downwards as indicated by an increase in OPD to $2.4 \mathrm{~mm}$ (Table 2) and peak in consumption at the oxic-anoxic boundary in Fig. 6. The $50 \mathrm{~mm}$ cut sediment exhibited a similar subsurface peak in $\mathrm{O}_{2}$ consumption but OPD had increased to only $1.4 \mathrm{~mm}$, apparently due to the presence of slowly reacting iron sulphides in the uppermost sediment layer as evidenced by darker coloration of cut surfaces and our voltammetric profiles.

The OPD and DOU of cores cut to $5 \mathrm{~mm}$ depth had not reached pretreatment levels after 20 to $24 \mathrm{~h}$ suggesting that even surface disruption by small mobile epifauna, such as surface-dwelling mollusks, can create lasting chemical signatures at the sedimentwater interface. If this is so, then our predisturbance measurements should reflect such signatures. A strong disturbance before sampling would be indicated by large variations in the observed variables because replicate measurements may have been conducted in sediments that had been displaced from different depths at different times. Spatial variability in the distribution and consumption of $\mathrm{O}_{2}$ seems a common feature of marine cohesive sediments (Glud 2008) and, in fact, our pretreatment (up to 30 min before cutting) measurements indicated such variability. Interpretation of the predisturbance results is not straightforward, however, because some cores were exposed to different flow speeds before measurement (Table 1). If previous exposure to fast flow affected the $\left[\mathrm{O}_{2}\right]$ gradients measured under conditions of slow flow, then measurements in such cores (gray squares in Fig. 3) should have revealed higher $\left[\mathrm{O}_{2}\right]_{\mathrm{zo}}$ and lower DOU than measurements in cores that were not previously exposed to fast flow (open squares in Fig. 3). Similarly, if previous periods of slow flow affected the gradient measured in the DBL during fast-flow treatments, then sediments that experienced such periods (gray triangles in Fig. 3) should have lower $\left[\mathrm{O}_{2}\right]_{\mathrm{z} 0}$ and higher DOU than those that experienced preceding fast flow. No such differences were apparent suggesting that the variation in DOU of the pretreatment sediment reflects variability in the distribution and consumption of $\mathrm{O}_{2}$ presumably caused by past displacement of slowly reacting sediment constituents.

Immediately after treatment $(<1 \mathrm{~min})$ the $50 \mathrm{~mm}$ cut cores consumed significantly more $\mathrm{O}_{2}$ under conditions of fast flow than under slow flow, but $1 \mathrm{~h}$ later there was no difference between flow treatments. However, when an outlier from these data was removed a significant difference was observed and, moreover, under fast flows there was also a significant difference between the average DOUs of 5 and $50 \mathrm{~mm}$ cut cores. That is, similar effects of flow speed and disturbance depth on the sediment DOU were evident immediately after disturbance $(<1 \mathrm{~min})$ and $1 \mathrm{~h}$ later. We conclude that the $50 \mathrm{~mm}$ cut cores demanded $\mathrm{O}_{2}$ at a rate that exceeded the supply by diffusion across the DBL. In other words, diffusion across the DBL limited the oxidation of the sediment from $50 \mathrm{~mm}$ depth but not that of the $5 \mathrm{~mm}$ cut cores.

The effect of flow speed on the distribution and consumption of $\mathrm{O}_{2}$ should have diminished as the sediment oxidation proceeded during the 20 to $24 \mathrm{~h}$ following treatment. However, our measurements showed that even after prolonged exposure to flume flow the 2 sediments responded differently to an abrupt increase in flow speed. Given $\left[\mathrm{O}_{2}\right]_{\mathrm{z} 0}$ was $\sim 77 \%$ saturation for both treatments before an increase in flow speed (Fig. 7), $\left[\mathrm{O}_{2}\right]_{\mathrm{z} 0}$ in sediment from which the upper $5 \mathrm{~mm}$ had been removed altered within $30 \mathrm{~min}$ so that the $\left[\mathrm{O}_{2}\right]$ gradient in the DBL was similar to that observed under conditions of slow flow. The $\left[\mathrm{O}_{2}\right]_{\mathrm{z} 0}$ measured shortly after flow acceleration do not represent a new steadystate situation but merely reflect that the porewater $\mathrm{O}_{2}$ concentration can respond quickly to changes in the DBL thickness. In contrast, $\left[\mathrm{O}_{2}\right]_{\mathrm{z} 0}$ in cores from which $50 \mathrm{~mm}$ of surface sediment was removed changed only slightly within 54 min following an increase in flow speed, resulting in a steeper $\mathrm{O}_{2}$ gradient in the DBL. The sediment $\mathrm{O}_{2}$ profile is the result of the 'resistance' in the DBL/sediment to $\mathrm{O}_{2}$ transport and the rate at which the sediment can consume $\mathrm{O}_{2}$. Sediment with a small OPD (such as for the $50 \mathrm{~mm}$ cut sediment) will have a proportionally larger part of this resistance in the DBL and the $\mathrm{O}_{2}$ gradient in the DBL will thus be more susceptible to changes in DBL thickness. $\left[\mathrm{O}_{2}\right]_{\mathrm{z} 0}$ on the other hand, will be more stable under conditions of fluctuating flow speeds compared with $\left[\mathrm{O}_{2}\right]_{\mathrm{z} 0}$ of more oxidised sediment with higher OPD.

We estimated the sediment $\mathrm{O}_{2}$ consumption rates from both the $\left[\mathrm{O}_{2}\right]$ gradients in the DBL and from the $\left[\mathrm{O}_{2}\right]$ gradient in the sediment. The resulting rates, DOU and $R$ (total depth-integrated sediment $\mathrm{O}_{2}$ consumption), respectively, differed from each other, but followed similar trends for each of the 2 sediment treatments. An offset between these 2 estimates is commonly observed (see Glud 2008 and literature cited therein). In our study, 2 effects may have been important. Firstly, perturbation of the flow velocity field as the microelectrode approached the sediment surface reduced the thickness of the DBL, leading to an increase in the steepness of the DBL $\left[\mathrm{O}_{2}\right]$ gradient and overestimation of DOU (Glud et al. 1994). Secondly, small-scale mixing by meiofauna may have enhanced solute transport by a factor of 1.5 to 2.0 (Aller \& Aller 1992, Rysgaard et al. 2000, Berg et al. 2001), an effect not accounted for in our estimates of $R$.

The experimental approach in this study required control of the topography of the sediment surface - a 
property that affects the rates of sediment-water solute exchange (but see Røy et al. 2005). To do so, we wirecut a slice off the sediment core and removed this slice from the bottom of the flume. This procedure mimicked the effect of some macrobenthic species, such as burrowing crabs and heart urchins, that displace sediment from depth to the sediment surface (benthic feeding fishes, skates and rays will have similar effects). However, unlike the natural environment, it prevented colonisation of the freshly exposed surface sediment by, for example, protists and invertebrates from the surrounding sediment. Such colonisation can increase the solute exchange between the freshly exposed sediment and overlying seawater over time and so affect its oxidation. However, some species may not colonise the sediment until oxidation has occurred to a certain degree (Gamenick et al. 1996). There are a number of other processes that may also influence oxidation rates of disturbed sediment and possibly account for differences between 5 and $50 \mathrm{~mm}$ cut treatments. Some bacteria grow slowly (e.g. nitrifying bacteria) so that reestablishment of their activity may take days or even weeks (Wallenstein et al. 2006). Seasonal variations in seawater and sediment temperature will affect the kinetics of microbial and chemical reactions involved in the recovery of the surface sediment. In addition, the surface sediment of the $50 \mathrm{~mm}$ cut cores probably differed from the $5 \mathrm{~mm}$ cut cores not only in its faunal colonisation, but also in the ratio of porewater to sediment particle surface, and thus in the area of potentially important (biogeochemically active) biofilms.

\section{CONCLUSIONS}

Our measurements indicate that disturbed sediment oxidised rapidly during the first minutes after contact with oxygenated seawater and then reached a 'quasi stable state' characterised by very slow changes in $\mathrm{O}_{2}$ distribution and flux due to gradual oxidation of reduced solids. Distribution and flux of $\mathrm{O}_{2}$ in 'quasi stable state' sediment are functions of its reduced solids content (disturbance depth); sediments disrupted to $50 \mathrm{~mm}$ maintained low $\mathrm{O}_{2}$ penetration and surface $\left[\mathrm{O}_{2}\right]$, and high rates of diffusive $\mathrm{O}_{2}$ uptake for at least $1 \mathrm{~d}$. These results confirm our hypothesis and previous theoretical analyses by Glud et al. (2007) suggesting that a disturbance of diagenetically active coastal sediment that involves oxidation of reduced solids can alter the chemistry of the sediment-water interface for days. Our results also indicate that the chemical properties of patches of disturbed sediment may be speciesspecific because they will be functions of the depth from which the sediment was displaced and the frequency of displacement. This effect will be most pro- nounced in sediment in which steep vertical gradients in the content of reduced solids exist. However, such gradients may not exist if large bioturbators such as sea urchins, brittle stars and mud crabs heavily rework the sediment (Williamson et al. 1999).

We found that the effect of flow speed on the recovery of the sediment surface chemistry depends on the depth of disturbance; diffusive transport of $\mathrm{O}_{2}$ across the DBL limited the oxidation of the sediment from $50 \mathrm{~mm}$ depth but not that of the $5 \mathrm{~mm}$ cut cores. The implications of such differences deserve further investigation. An interesting question is if variations in the speed of the flow above cohesive 'quasi-stable' sediment generate cues that reveal information about subsurface sediment properties to infaunal recruits. Invertebrate larvae or postsettlement juveniles may use such differences during settlement: more stable DBL $\left[\mathrm{O}_{2}\right]$ gradients but fluctuating $\left[\mathrm{O}_{2}\right]_{\mathrm{z} 0}$ under conditions of changing flow speed indicate well-oxidised sediment, whereas a fluctuating DBL $\left[\mathrm{O}_{2}\right]$ gradient but stable $\left[\mathrm{O}_{2}\right]_{\mathrm{zo}}$ indicate that sediment contains a relatively large pool of reduced components. These cues are directly linked to the redox status of subsurface sediment and so may allow recruits of infaunal species to assess the subsurface environment without probing this sediment.

Acknowledgements. We thank P. Berg, H. Giles, J. Meadows, A. Vopel, and 3 anonymous reviewers for comments on an early draft. The New Zealand Foundation for Research, Science and Technology (C01X0307) funded the research.

\section{LITERATURE CITED}

Aller RC, Aller JY (1992) Meiofauna and solute transport in marine muds. Limnol Oceanogr 37:1018-1033

Archie GE (1942) The electrical resistivity log as an aid in determining some reservoir characteristics. Trans AIME 146:54-62

Berg P, Risgaard-Petersen N, Rysgaard S (1998) Interpretation of measured concentration profiles in sediment pore water. Limnol Oceanogr 43:1500-1510

> Berg P, Rysgaard S, Funch P, Sejr MK (2001) Effects of bioturbation on solutes and solids in marine sediments. Aquat Microb Ecol 26:81-94

Berg P, Rysgaard S, Thamdrup B (2003) Dynamic modelling of early diagenesis and nutrient cycling. A case study in an Arctic marine sediment. Am J Sci 303:905-955

Berner RA (1980) Early diagenesis - a theoretical approach. Princeton University Press, Princeton, NJ

Biles CL, Paterson DM, Ford RB, Solan M, Raffaelli DG (2002) Bioturbation, ecosystem functioning and community structure. Hydrol Earth Syst Sci 6:999-1005

Brendel PJ, Luther GW III (1995) Development of a gold amalgam voltammetric microelectrode for the determination of dissolved $\mathrm{Fe}, \mathrm{Mn}, \mathrm{O}_{2}$, and $\mathrm{S}(-\mathrm{II})$ in porewaters of marine and freshwater sediments. Environ Sci Technol 29: 751-761

Broecker WS, Peng TH (1974) Gas exchange rates between air and sea. Tellus 26:185-190

Finelli CM, Hart DD, Fonseca DM (1999) Evaluating the spa- 
tial resolution of an acoustic Doppler velocimeter and the consequences for measuring near bed flows. Limnol Oceanogr 44:1793-1801

> Gamenick I, Jahn A, Vopel K, Giere O (1996) Hypoxia and sulphide as structuring factors in a macrozoobenthic community on the Baltic Sea shore: colonisation studies and tolerance experiments. Mar Ecol Prog Ser 144:73-85

Glud RN (2008) Oxygen dynamics of marine sediment. Mar Biol Res 4:243-289

Glud RN, Gundersen JK, Revsbech NP, Jørgensen BB (1994) Effects on the diffusive boundary layer imposed by microelectrodes. Limnol Oceanogr 39:462-467

Glud RN, Berg P, Fossing H, Jørgensen BB (2007) Effects of the diffusive boundary layer on benthic mineralization and $\mathrm{O}_{2}$ distribution: a theoretical model analysis. Limnol Oceanogr 52:547-557

Jørgensen BB, Boudreau BP (2001) Diagenesis and sedimentwater exchange. In: Boudreau BP, Jørgensen BB (eds) The benthic boundary layer. Oxford University Press, Oxford, p 211-244

Jørgensen BB, Des Marais DJ (1990) The diffusive boundary layer of sediments: oxygen microgradients over a microbial mat. Limnol Oceanogr 35:1343-1355

Jørgensen BB, Revsbech NP (1985) Diffusive boundary layers and the oxygen uptake of sediments and detritus. Limnol Oceanogr 30:111-122

Marinelli RL, Woodin SA (2002) Experimental evidence for linkages between infaunal recruitment, disturbance, and sediment surface chemistry. Limnol Oceanogr 47: 221-229

Marinelli RL, Woodin SA (2004) Disturbance and recruitment: a test of solute and substrate specificity using Mercenaria mercenaria and Capitella sp. 1. Mar Ecol Prog Ser 269: 209-221

Norling K, Rosenberg R, Hulth S, Grémare A, Bonsdorff E (2007) Importance of functional biodiversity and speciesspecific traits of benthic fauna for ecosystem functions in marine sediment. Mar Ecol Prog Ser 332:11-23

Rasmussen H, Jørgensen BB (1992) Microelectrode studies of seasonal oxygen uptake in a coastal sediment: role of molecular diffusion. Mar Ecol Prog Ser 81:289-303

Editorial responsibility: Matthias Seaman, Oldendorf/Luhe, Germany
Revsbech NP (1989) An oxygen microelectrode with a guard cathode. Limnol Oceanogr 34:474-478

Revsbech NP, Nielsen LP, Ramsing NB (1998) A novel microsensor for determination of apparent diffusivity in sediments. Limnol Oceanogr 43:986-992

Røy H, Huettel M, Jørgensen BB (2005) The influence of topography on the functional exchange surface of marine soft sediments, assessed from sediment topography measured in situ. Limnol Oceanogr 50:106-112

Rysgaard S, Christensen PB, Sørensen MV, Funch P, Berg P (2000) Marine meiofauna, carbon and nitrogen mineralization in sandy and soft sediments of Disko Bay, West Greenland. Aquat Microb Ecol 21:59-71

Ullman WJ, Aller RC (1982) Diffusion coefficients in nearshore marine sediments. Limnol Oceanogr 27:552-556

Verma SP, Quiroz-Ruiz A (2006) Critical values for six Dixon tests for outliers in normal samples up to size 100, and applications in sciences and engineering. Revista Mexicana de Ciencias Geologicas 23:133-161

> Vopel K, Vopel A, Thistle D, Hancock N (2007) Effects of spatangoid heart urchins on $\mathrm{O}_{2}$ supply into coastal sediment. Mar Ecol Prog Ser 333:161-171

> Wallenstein MD, Myrold DD, Firestone M, Voytek M (2006) Environmental controls on denitrifying communities and denitrifcation rates: insights from molecular methods. Ecol Appl 16:2143-2152

> Widdows J, Blauw A, Heip CHR, Herman PMJ and others (2004) Role of physical and biological processes in sediment dynamics of a tidal flat in Westerschelde Estuary, SW Netherlands. Mar Ecol Prog Ser 274:41-56

Williamson RB, Wilcock RJ, Wise BE, Pickmere SE (1999) Effect of burrowing by the crab Helice crassa on chemistry of intertidal muddy sediment. Environ Toxicol Chem 18: 2078-2086

Woodin SA, Marinelli RL, Lindsay SM (1998) Process-specific cues for recruitment in sedimentary environments: Geochemical signals? J Mar Res 56:535-558

Yuan-Hui L, Gregory S (1974) Diffusion of ions in sea water and in deep-sea sediments. Geochim Cosmochim Acta 38: $703-714$

Submitted: December 18, 2008; Accepted: June 24, 2009

Proofs received from author(s): October 1, 2009 